$1-1-2019$

\title{
Teaching Communication Skills in Transactional Simulations
}

Eric J. Gouvin

Western New England University School of Law

Katherine M. Koops

Emory University School of aw

James E. Moliterno

Washington and Lee University School of Law

Carol Morgan

University of Georgia School of Law, cemorgan@uga.edu

Carol D. Newman

University of Missouri School of Law

p bSRN

\section{Repository Citation}

Eric J. Gouvin, Katherine M. Koops, James E. Moliterno, Carol Morgan, and Carol D. Newman, Teaching Communication Skills in Transactional Simulations , 20 Transactions: Tenn. J. Bus. L. 429 (2019),

Available at: https://digitalcommons.law.uga.edu/fac_artchop/1301

This Article is brought to you for free and open access by the Faculty Scholarship at Digital Commons @ University of Georgia School of Law. It has been accepted for inclusion in Scholarly Works by an authorized administrator of Digital Commons @ University of Georgia School of Law. Please share how you have benefited from this access For more information, please contact tstriepe@uga.edu. 


\title{
Teaching Communication SKILls IN TransaCTIONAL SIMULATIONS
}

\author{
Eric J. Gouvin, ${ }^{*}$ Katherine M. Koops, ${ }^{* *}$ James E. Moliterno, ${ }^{* * *}$ \\ Carol E. Morgan ${ }^{* * * *}$ \& Carol D. Newman ${ }^{* * * *}$
}

\begin{abstract}
This article describes the role of communication exercises in transactional law and skills education, and provides several examples of such exercises. After a discussion of fundamental differences between communication in the context of litigation and transactional law, the article discusses exercises designed to improve written communication skills, including the use of e-mail, in the context of transactional law. It follows with a similar discussion of exercises focusing on oral communication skills, including listening, interviewing, counseling, negotiation, and presentations. The article concludes with examples of exercises combining oral and written communication skills in the context of simulated transactions.
\end{abstract}

\section{General Introduction}

Communication skills are vital for practicing attorneys, and law students benefit strongly from opportunities to practice and develop their communication skills. In particular, carefully constructed simulation exercises can help students find their voices and become more confident in their communications, learn how to address different audiences, improve writing skills, including grammar and accuracy, and learn to speak clearly and effectively. In focusing on opportunities for students to develop overall professional communication skills, this article emphasizes

\footnotetext{
* Professor of Law and Dean Emeritus, Western New England University School of Law.

** Assistant Director, Center for Transactional Law and Practice and Adjunct Professor, Emory University School of Law.

*** Vincent Bradford Professor of Law, Washington and Lee University School of Law.

**** Clinical Professor and Director, Business Law and Ethics Program, University of Georgia School of Law.

${ }^{* * * * *}$ Transactional Professor of Law, University of Missouri School of Law.
} 
the special need to teach skills for lawyer communications outside the context of a dispute.

\section{The Importance of Context: Transactional Law vs. Litigation}

In rough terms, lawyers may be divided into two groups: those whose work looks forward and those whose work looks backward. This simple division says much about a lawyer's ethical and legal responsibility and about lawyer-client relationships, including lawyer-client communication and control.

First, when a lawyer's work looks backward, as is typically the case in litigation, the lawyer bears no moral, ethical or legal responsibility for the past acts of the client. The lawyer simply represents the client in the client's interactions with the legal system. But the lawyer whose work looks forward is a partner with the client in creating the future and future facts. The transactional lawyer assists in creating employer-employee relationships for the client who owns a business, in creating a set of legal relationships for the client setting up a tax plan or a new entity, or the debt relationship between a client and a lender, for example. All these transactional lawyer acts make events happen in the future that would not otherwise have occurred. In these respects, the forward-looking transactional lawyer bears a measure of ethical and legal responsibility with the client for the quality of those future facts.

Second, and partly, but not entirely driven by the first aspect, interactions between the backward-looking lawyer and her client can be vastly different than those between the forward-looking lawyer and her client. The litigation client is truly on the lawyer's playing field and will normally defer to the lawyer's judgment about how to play the litigation game. Other than repeat litigation players who sometimes think they know the game as well as their lawyers do, litigation clients feel relatively helpless in the land of lawyers and courts. As a result, the interactions and communications between litigation lawyers and clients favor strongly the expertise of the lawyer, and in general, wise clients reasonably defer to the lawyer. But the transactional client is usually different from the litigation client. The transactional client is doing business and the lawyer is less knowledgeable about this playing field than is the client. The consequence is that the communication favors the client's superior knowledge and expertise, as it should. The client is far more likely to define the scope of 
the lawyer's work- "tell me the legal implications and leave the business judgments to me.”

Our students in transactional courses, and especially simulations, need to see this from the outset. They have been conditioned from the first day of law school to think of the lawyer's work as litigation work. They have little understanding of the work of transactional lawyers, whose fondest hope is to keep their client's situation from being excerpted in a law school casebook. In dealing with a simulated business client (say Morgan Buyer), an ill-prepared student is liable to tell the client (as a litigation lawyer surely would), "do not communicate with Lee Seller directly about this matter." A well-prepared simulated client might very well respond by telling the lawyer to stick with analyzing law and leave the personal relationships to the business client. The business client wants to be far more in charge of everything, except the pure analysis of law. And even here, the client is fairly likely to tell the lawyer to "figure out the law so that I can do what I want."

Without a foundational understanding of these differences between business and litigation clients, students will usually collapse their expectations into the default of litigation-what they have read in casebooks and seen in popular culture. Students understand transactional work and tasks far better when they have this foundational understanding of the lawyer-client relationship and the litigation-transactional divide.

A Task Force of the Business Law Education Committee of the ABA's Section on Business Law has undertaken an effort to identify the core skills and competencies that new business lawyers should either possess upon leaving law school or acquire as their professional life begins. ${ }^{1}$

The inventory of key competencies . . . employs the framework articulated in the MacCrate Report, which lists essential skills and values for lawyers generally, but looks at those attributes through the lens of the business lawyer. [mportantly, i]n addition to the MacCrate skills and values, the Task Force has added a set of behavioral competencies of effective business lawyers. ${ }^{2}$

\footnotetext{
${ }^{1}$ Barbara Wagner et al., Defining Key Competencies for Business Lanyers: Report of the Task Force on Defining Key Competencies for Business Lanyers, 72 Bus. Law. 101, 110 (2017).

${ }^{2}$ Id. at 112
} 
For legal educators, the current ABA standards for accreditation of law schools creates a compelling incentive to assess competencies in order to articulate meaningful "learning outcomes." 3 Since the ABA standards also require law schools to implement mechanisms to evaluate "the school's effectiveness in achieving its stated educational objectives," the inventory of transactional law competencies may be useful to law schools in complying with those provisions as they relate to the business law curriculum. The articulation of these key competencies may be an aid to law school faculties in developing curricula, to law teachers in designing specific courses, to law students in planning a course of study, and to the business law bar in identifying areas in which to devote resources for associate development.

\section{Written Communication}

\section{Background}

Typical written transactional communications include communications with (1) the client, (2) the supervising attorney or other members of the legal team representing the client, (3) counsel for the other side, or (4) third parties, such as accountants or auditors. Although these parties also receive written communications in the context of legal or business disputes, the context of forward-looking transactions generally changes the nature of transactional communications from lawyers.

\section{Letters and Memos}

For example, typical letters and memos to a supervising attorney, a client, or counsel for the other side, often range from straightforward communications arranging meetings or transmitting information, to more

\footnotetext{
3 See Am. Bar Ass'N, ABA Standards And Rules of Procedure for Approval of LAW SCHOOLS 2014-2015 \302, http://www.americanbar.org/content/dam/aba/publications/misc/legal_education/St andards/2014_2015_aba_standards_chapter3.authcheckdam.pdf (requiring that law schools establish learning outcomes).

4 See Am. Bar Ass'N, ABA Standards and Rules of Procedure for Approval of LAW SCHOOLS 2014-2015 \204, http://www.americanbar.org/content/dam/aba/publications/misc/legal_education/St andards/2014_2015_aba_standards_chapter2.authcheckdam.pdf (requiring, as part of the law school's pre-inspection self-study, an evaluation of the school's effectiveness in achieving the educational objectives).
} 
complicated transmittal communications, such as cover letters, sending copies of documents, drafts of agreements under consideration or under negotiation, or memos regarding specific legal issues. When drafts of agreements under negotiation are exchanged with counsel for the other side, the communications can become much more complex, as they often include explanations that advocate for specific language or issues that favor one's client. Students must learn to consider various legal and ethical issues in determining the appropriate content, form, and tone of a written communication to a specific type of addressee; and they must learn how to deal with varying expectations of formality, especially when combining friendly tone with formal legal communications. ${ }^{5}$ In all these considerations, students must also recognize inherent advantages and disadvantages in the uses of appropriate media of communication, especially as electronic communication is now the mode of delivery for most traditional transactional written communications.

\section{Letter to Client Exercise}

One exercise to help students begin to identify and focus on the need for careful language in communicating with clients is to have the students, as a group, review a grammatically flawed letter after they have completed background readings on grammar and writing style. In using this exercise, the professor projects the letter on the screen and then goes around the room, one student at a time, analyzing each sentence for grammatical or usage errors. The student is asked to identify and discuss what is wrong and then to suggest, with real-time editing, a better way to convey the idea. This exercise is also an opportunity to introduce students to traditional proofreading symbols, so that students will know how to mark up an actual paper document without relying exclusively on electronic edits and comparisons of documents.

\footnotetext{
${ }^{5}$ Students must learn to recognize — and handle differently — special types of third-party communications that require specific knowledge and experience as a threshold for communication. Two obvious examples are (1) legal opinions to third parties (often called "third-party opinion letters"), which are often unfamiliar to litigators who do not practice in the area of commercial transactions, and (2) audit letter responses. These two types of third-party communications are beyond the scope of this article, but students must still be reminded that these types of communications require sophisticated knowledge and experience in the specific subjects and protocols in determining the appropriateness, scope, and content of these communications. Failure to recognize the purpose and practice of these types of third-party communications could result in unintended assumption of liability in the delivery of these written communications.
} 


\section{Engagement Letter Exercise}

After students have learned to focus on grammar and usage, a helpful exercise is to ask the students to mark up someone else's draft memo of an engagement letter-this time in the role of a supervising attorney giving feedback. Students are asked to pay careful attention to the draft and to make appropriate comments and edits. In so doing, they become even more familiar with the types of issues that arise when imprecise or incorrect language is used and with proofreading symbols typically used to mark up internal drafts.

\section{Cover Memo Exercise}

Finally, another preliminary exercise introduces students to potential problems that might arise from generally reassuring a client about future actions and consequences without careful consideration of the language used. This exercise uses a form of a flawed cover memo to a client, in which the student is asked to try to find one or more sentences that might (1) overstate or promise results, (2) create confusion in the client's understanding of the transaction, (3) describe agreements for which the client has not had an opportunity to make its own decision, (4) suggest actions that might not be in the client's best interests, or (5) suggest actions that might create ethical issues regarding the attorney's role in the transaction. The discussion of these five questions should lead to identification of typical issues of ethics and professionalism in transactional representations, the role of a transactional attorney in a forward-looking business transaction, including opportunities for the lawyer's legal advice and the role of the client in making its own business decisions, and the need for clear and carefully chosen language for communication.

\section{E-mail Communications}

Today's students have also grown up in a world where even oral communications have been supplanted by written electronic communications. As a result, it is important to emphasize to students that electronic texting, chatting, and posting of communications, that they use conversationally, are still written communications, that must be treated as written communications. These communications might be subject to unintended discoverability. In discussing the likely use of electronic transmittal and storage of current written communications, it is important to emphasize the perils, not only of the choices of methods of electronic communication, but also of the ease with which confidentiality can be lost. 
Examples in which confidentiality can be easily lost include accidental autofill of e-mail addresses or the forwarding of e-mails to new parties without attention to possible subject changes during the course of an email thread, such as inviting a new party to a meeting, when the original email contains confidential advice about the subject to be discussed at the meeting.

In addition, students are often unaware of the dangers of metadata and are relatively naïve about document enhancements, such as comments and "track changes." For example, even after a classroom exercise on the dangers of documents with metadata, one student accidentally submitted a homework assignment marking various "track changes" and included comments that the student had not intended to submit. The student did not realize that the metadata could still be there even if the student could not see the metadata on the computer screen when the document was emailed.

E-mail negotiations are also full of opportunities for misunderstandings, not only because of the loss of personal conversational tone in e-mails, but especially because of the loss of spontaneous interruption of live conversations. When a misunderstanding or misassumption occurs in a live conversation, another conversant often interrupts to explain or clarify the misunderstanding; when a misunderstanding occurs in e-mail, the author continues to base the language that follows on the misunderstanding, thus widening the gap of misunderstanding by the time the recipient reads it.

\section{E-mail-Only Negotiation Exercise}

One helpful way to demonstrate the strengths and weaknesses of e-mail in negotiations is to conduct an e-mail-only negotiation exercise. In this exercise, students are divided into counsel for two different parties, such as a buyer or a seller. After receiving client instructions and background facts for the negotiation, the student lawyers are paired off for e-mail negotiations for one hour. They are not permitted to communicate with each other by any other means, such as by telephone, in personal conversation, or by being in the same room to observe body language. After an hour, they attend a debriefing session in which they discuss the pros and cons of e-mail communication in the context of transactional negotiations. In these debriefings, they often observe that email is helpful in setting agendas of items to be discussed, in exchanging opening concerns, and in exchanging specific language to be negotiated or revised. However, they generally agree that a conversation often helps get 
the parties to an agreement-or at least an understanding of open issuesmuch more efficiently and accurately.

\section{Oral Communication}

\section{Background}

Strong oral communications skills are as vital as strong written communication skills for transactional lawyers. Consider all the times that transactional lawyers engage in oral communication: meeting with clients or prospective clients, interviewing clients, advising and counseling clients, discussing a transaction with business advisors, negotiating a contract, making a presentation to a client or a board, and more. In all these settings, the lawyer needs to be able to communicate clearly, concisely, and confidently.

Law schools have a prime opportunity to help students develop oral communication skills in transactional simulations. As a key part of this training, students will appreciate that oral communication for transactional lawyers is relational-it is about creating dialogue with others. This characteristic is a notable difference from the litigation advocacy training that they receive in law school.

The first step is to make the classroom a safe space for students to practice their skills. They need to be comfortable speaking in class and having discussions and interactions with each other. Some students say they are shy, introverted, and do not feel comfortable participating in class. Our role as professors is to help these students "come out of their shell" and realize the value they can provide when they find their voice. They need to understand that they will not be effective as lawyers if they sit in a meeting in total silence. On the other hand, some students dominate every class discussion and drown out other voices. The challenge is to help these students learn to listen more and participate with more discretion. Other students say that they are willing to participate, but they cannot think of good questions to ask or do not have anything to contribute. Professors need to help these students gain more confidence in their critical thinking skills and their ability to ask good questions.

\section{Creating a Safe Classroom}

How do we create a safe space in the classroom for all our students? Ice-breakers at the beginning of the semester are helpful. One simple ice-breaker is to have students interview someone in the class they do not know well for three- to five-minutes, without taking notes, and 
then reverse roles. Afterward, each student reports on the interview to the rest of the class, noting three-to-five distinctive things they learned about the other student. Students often discover common interests or connections with each other. This exercise reinforces the value of relationship-building.

During the semester, other exercises can strengthen the safety of the classroom for communications. These include break-out groups, "turn to your neighbor" discussions, and team work. In a comfortable, safe class setting, professors can implement practical exercises that will help students develop a variety of skills to improve oral communication.

\section{Listening Skills}

Students need to realize that oral communication is not just about talking; listening is one of the most important skills for a good communicator. One exercise to practice listening skills is a three-part role play. Prior to this exercise, the class has a brief discussion about the attributes of active listening. In the exercise, one student is the talker, one is the listener, and one is the coach/observer. The talker may describe a challenge that he or she is facing, or the professor may provide a scenario. The coach/observer has a written list of criteria for active listening skills, which is attached as Appendix $A$. The talker discusses the situation for about three minutes, and the listener practices listening skills and tries to resist the urge to talk and fix the problem. Afterward, the coach provides feedback to the listener.

\section{Peer Debriefing Exercise}

A simple listening exercise can be incorporated into a peer debriefing. In this exercise, after pairs of students have completed a negotiation simulation, the students are asked to think about the traits of an effective transactional negotiator. Then they are asked to think of two ways in which the simulated counsel for the other side were effective as transactional lawyers. When all students have thought of the two characteristics, they are asked to meet with counsel for the other side and tell the other side's counsel the two things that were especially good or effective.

When all negotiating pairs or groups have exchanged their positive observations, the professor leads a debriefing in which the goal is to assemble an overall list of traits of effective transactional negotiators. The "listening twist" to this exercise is to ask the recipients of the positive feedback what they did well. Inevitably, this question evokes a surprised 
reaction on the part of some students, for they are fully prepared to say what they told their negotiating counterparts, but they have not always listened so closely to carefully considered compliments from the other side. This exercise often leads to another quick conversation among the negotiating groups to be able to report on positive feedback that each side received. Most importantly, it enables the professor to introduce a discussion about the importance of truly listening to feedback-positive as well as negative-and to using genuine positive feedback from the "other side" as reinforcement of strengths that will be beneficial during one's career as a transactional attorney.

\section{Initial Client Interview Exercise}

An exercise that combines listening and interviewing skills involves two rounds of simulated meetings in which counsel meets with his or her client for the first time regarding the hypothetical sale of a business. Students play the role of a client in one round and the role of counsel in the other, which enables them to gain valuable perspective and experience in each role. The exercise is best done in a class that provides at least ninety minutes for preparation, engagement, and debrief and can be performed one-on-one or two-on-two, depending on class size.

Prior to class, the professor develops sets of "Buyer Facts" and "Seller Facts" describing the applicable party's business, operations, structure, stakeholders, and principal client concerns. Each fact statement is no longer than two pages and is organized clearly to facilitate student review. The facts may be presented to students in class, with time to review them, or before class, with instructions to keep them confidential. Students receive only one set of facts-either Buyer Facts or Seller Facts - and also receive handouts on effective client interviewing skills for when they play the role of counsel.

In Round One, the professor breaks the class into two groups: Seller Clients and Seller's Counsel. Students who have received the Seller Facts will play Seller Clients and have approximately ten minutes to review their facts. They are coached to answer only the questions asked and to respond to "yes or no" questions with "yes or no" answers. At the same time, the other students, who are playing Seller's Counsel, plan an initial interview with a client about which they know almost nothing. Their goal is to ask questions, listen to the client's responses, and prepare a list of business and legal issues that they will share with the class. 
After the students have prepared, they engage in a ten- to fifteenminute client interview. Students playing Seller's Counsel debrief the interviews, each listing in turn one thing they learned about the Seller or its business or legal concerns. When there are no new items to list, the Seller Clients describe which questions elicited the most information, whether they possessed material information they were not asked about, and how that information could have been obtained. In a short interview, students can be so focused on getting through a list of questions in a limited amount of time that they don't listen well to the answers or ask appropriate follow-up questions that elicit valuable information.

Round 2-the Buyer Interview - operates in the same way, except that students who played clients in Round 1 now play counsel in Round 2 and vice versa. This gives each student the opportunity to play both roles and gain relevant experience and perspective. In Round 2, the interviews tend to capture more information because students have already gained experience in asking appropriate questions, listening to the answers, and following up with additional questions as needed.

\section{Code of Conduct Exercise}

Another way to practice interviewing and counseling skills is a role-play involving a company's Code of Conduct or Code of Ethics, which is an easily accessible teaching tool. Most companies-public and private-post their Code of Conduct or Code of Ethics on their website. An added benefit of this exercise is that students discover another means of corporate governance: a company's Code of Conduct or Code of Ethics, which often exceeds the requirements of law and regulations and reflects a company's ethical culture.

In this role-play, a student acting as an employee approaches a student acting as corporate counsel for the company and asks about a situation that may be a violation of the company's Code of Conduct or Code of Ethics. A list of suggested scenarios is attached as Appendix B. An example involves an outside law firm offering an attorney on the legal staff tickets to the Masters, Super Bowl or NCAA championshipwhatever is in season. The student acting as an employee is coached to challenge and question the student acting as corporate counsel in an effort to mimic reality.

The student acting as corporate counsel responds to the employee, relying on the company's Code of Conduct or Code of Ethics. Students 
acting as attorneys do not receive any direction before the exercise about appropriate interviewing or counseling skills.

During the debriefing after the exercise, students acting as corporate counsel often recognize that their natural instinct is to jump in and immediately start giving their opinion or advice. They discover they need to stop and ask questions and gather information-in other words, they need to interview the employee and listen. Only then will they be able to counsel the employee in a reasoned, informed way. They also realize they need to be aware of their tone and approachability and to practice their creative problem-solving skills instead of giving an automatic "no." In addition to feedback by professors, students give feedback to each other in class-describing what was effective and what could be improved in the student's method of interviewing and counseling.

\section{Negotiation Skills}

Negotiation exercises are a valuable way to practice communication skills. Prior to any exercises, students will benefit from reading about and discussing basic negotiation skills, particularly in a transactional (as opposed to a litigation or dispute resolution) context. ${ }^{6}$

In contract drafting or deals classes, students can negotiate contract provisions or deal terms, with guidance from the professor as to the issues on each side. A number of textbooks have negotiation exercises, and Harvard's Program on Negotiation ${ }^{7}$ and Northwestern's Dispute Resolution Research Center ${ }^{8}$ offer simple and complex negotiation roleplays for a reasonable fee.

\footnotetext{
${ }^{6}$ Many negotiation resources are available. Three helpful books are ROGER FISHER ET AL., GetTing to Yes: Negotiating AgreEment Without Giving In (3d ed. 2011); G. Richard Shell, BARgaining for Advantage: Negotiation Strategies For Reasonable People (2d ed. 2006); and Deepak Malhotra \& Max H. Bazerman, Negotiation Genius: How to Overcome Obstacles and Achieve Brilliant RESUltS AT THE BARGAining TABLE AND BEyOND (2007). Summaries of GETTING TO YES can also be found on the Internet.
}

7 Program on Negot. Harv. L. SCH., https://www.pon.harvard.edu (last visited Aug. 25, 2018).

8 Nw. Kellogg Disp. Resol. Res. CTR., https://www.kellogg.northwestern.edu/research/drrc_last visited Aug. 25, 2018). 
Videotaped negotiation sessions offer a valuable teaching opportunity. A rubric to evaluate negotiation skills is attached as Appendix $\underline{C}$. Students use the same rubric to evaluate themselves and another videotaped negotiation by their peers. While students are not gleeful about being videotaped beforehand, they generally agree afterward that this experience is extremely beneficial. One of the greatest take-aways is that they discover their body language or nonverbal communication needs improvement.

Negotiation exercises also provide an ideal opportunity to discuss stylistic issues in communication. Some students tend to use hedging language ("sort of," "I'm not sure but," "I think/I believe," "this is the best way - right?") and inflections or up-speak at the end of sentences, which may signal insecurity to the other side. Professors can coach them to use stronger language ("I'm confident/I'm convinced") and stronger voices. Another common tendency is for some students to over-apologize, over-commiserate, and over-thank, and professors can work with them to strike more balanced power at the table. In addition, all students need to be aware of the tendency of some speakers to interrupt or speak over others at the table, and students can practice ways to be more sensitive and for all participants to speak up and be heard.

In addition, through negotiation exercises, the class can have an open discussion about how we all bring cultural biases to the tablewhether it's about someone's education, hometown, or station in lifeand that we need to be honest and recognize these biases, avoid them, and appreciate different perspectives.

\section{Presentation Skills}

Oral communication can be in both informal and formal settings. One of the best ways for students to practice communication skills in more formal settings is by making presentations. However, unless students get proper guidance in preparation and meaningful feedback, presentations are often not very useful.

To help students prepare, they can read about and discuss presentation techniques. ${ }^{9}$ Another way to prepare is for students to watch

\footnotetext{
9 See, e.g., Leah Wortham et al., Learning from Practice: A Text for EXPERIENTIAL LEgAL EDUCATION 469-88 (3d ed. 2016) (available online for a reasonable fee).
} 
TED Talks ${ }^{10}$ (search on the Internet for the most viewed talks), critique presentation methods, and determine what techniques, such as telling stories or using pictures, are effective and what they can incorporate in their presentations. Through preparation, students learn to focus more on the audience than on themselves. They learn to consider the key points the audience needs to take away from the presentation and the most effective ways to engage their audience. They also learn that they are likely to need to spend as much time on practicing the actual presentation as they do on preparing the content for the presentation.

A presentation may be informative or it may be persuasive. In a deals or mergers and acquisitions class, students can prepare presentations about current deals in the news and demonstrate the knowledge they have learned in class. In any simulation class, students can make a presentation on a relevant legal topic to their classmates.

As an example of a more persuasive presentation, students tailor a presentation to a particular audience (such as a board of directors) and provide a recommendation on how to handle a risk facing a company. In the process, students learn about appropriate communication methods for different audiences. In another exercise, students prepare and deliver an "elevator talk" or brief talking points for a prospective employer about the value they have gained from a simulation course. In some cases, law students are not adept at promoting themselves, and this exercise helps them talk about themselves in a safe but compelling way.

A suggested rubric for a professor's evaluation of student presentations is included as Appendix $D$. This rubric can be provided to students before the presentation to set expectations; in fact, students can play a role in determining the criteria on the rubric. The rubric can also be used after the presentation to provide feedback to students. Peers can also provide written feedback based on what they learned from a presentation, what went well, and what could be improved (see the Peer Evaluation form attached as Appendix E).

\section{Effective Use of Slides}

Students should also understand how to use slides appropriately in presentations. For many people, making a presentation means using presentation software, with PowerPoint being a typical example.

${ }_{10}$ TED, https://www.ted.com/talks (last visited Aug. 25, 2018). 
It has become fashionable to bash PowerPoint as a tool designed to squelch original thought and destroy effective communication. ${ }^{11}$ Although much of the criticism is insightful, too many detractors set up a "straw man" argument in which they rail against obviously bad practices. It is, of course, tedious to sit through a presentation in which the presenter is using PowerPoint as a teleprompter and just reading the speaking notes that the entire audience can see on the screen. One must ask in those situations, "Why do I need to be here when I can just read the slides later?"

Similarly, PowerPoint presentations sometimes contain extraneous animations, sound effects, and transitions that add nothing to the presentation and actually detract from it. Yet these criticisms are not an indictment of PowerPoint itself but are instead legitimate criticisms of how the software has been misused. Presenters can be inept at using the whiteboard, too, but we never hear calls for banning the whiteboard from presentations.

The most important thing to remember is that the presentation is not about the PowerPoint - the presentation software is merely a tool to tell the story. Therefore, the biggest challenge is to get the content rightmake it exciting, compelling and interesting. The basic content must carry the heavy load. In a classic spoof of PowerPoint, internet pioneer Peter Norvig asked the question "What if Lincoln had PowerPoint at Gettysburg?" 12 The send-up is quite funny, but the take-away should be obvious: if your material is the Gettysburg Address, then just use the Gettysburg Address; you do not need presentation software to help with your communication.

Unfortunately, students rarely are working with material as compelling as the Gettysburg Address. As a result, PowerPoint can be a useful tool, particularly in the following situations:

\section{Presenting Key Text.}

With regard to statutes and other important texts, PowerPoint can be a significant aid to clear communication. Getting the text up on the screen so the presenter and the audience are both reading from the same page can be a big help for audience members trying to follow along. The presenter can use a laser pointer to indicate key passages that are the focus

\footnotetext{
11 See Michael Flocker, Death By PowerPoint (2006).

12 The Gettysburg Powerpoint Presentation, https://norvig.com/Gettysburg (last visited Aug. 25, 2018).
} 
of the discussion. Sometimes it helps to have a slide ready to highlight key language to drive a point home for the audience by using a different color font. Sophisticated users can incorporate hyperlinks to enable crossreferencing to statutory and regulatory materials.

\section{Generating Clear and Sophisticated Graphics.}

For items that could be drawn on a whiteboard, PowerPoint speeds up the presentation a bit because the presenter does not actually need to draw the object. For people who are artistically challenged, PowerPoint allows the presenter to incorporate higher production values into visual aids with nicely prepared graphics instead of terrible handdrawn figures.

Often, presentations explaining legal ideas are organized according to a chronology. PowerPoint is very useful in creating timelines to illustrate those chains of events. Using the software, the timeline can be animated, so that key points are revealed only when the live discussion calls for them to be revealed.

Similarly, data that is best presented graphically can be communicated very effectively in PowerPoint. The software allows the presenter to get the graphs right and not worry about things lining up. It allows for legible highlighting through shading or font color changes, and graphs can be animated to change if necessary.

\section{Enlivening Presentations.}

Let's face it, legal issues can be dry. A special graphic or a little joke to lighten things up goes a long way and re-engages an audience whose attention is drifting. PowerPoint, as a visual medium, allows a presenter to enliven presentations by supplementing oral communication with compelling visual aids. Nearly every case has some visual aid that can help it come alive, be it a picture of the parties, the object of the lawsuit, or a movie clip involving the subject. PowerPoint also allows presenters to use sound effects, but they should be used sparingly and not be linked to bullet points.

\section{Presenting Numbers Clearly.}

Finally, PowerPoint is an excellent communication tool when numbers are crucial to a clear understanding. Preparing slides in advance allows the presenter to get everything right, make sure the numbers add up, ensure they are legible, and assess whether they move the presentation 
forward. For sophisticated users, it might be even better to toggle to a spreadsheet or have a hyperlink.

While PowerPoint is by no means a godsend, and there are times when it's inappropriate, students will be called upon to use it on many occasions, both in law school and in practice. Understanding and mastering its effective use will aid students in communicating information that is difficult to convey with spoken words alone.

\section{Putting it All Together}

The preceding exercises focus on oral or written communication as separate skills in the context of transactional law. More sophisticated exercises and simulations can combine these skills with others, such as issue-spotting, research, legal analysis, connecting business interests with legal requirements, project management and organization, and recognizing and resolving ethical issues. The following exercises exemplify combinations of these skills.

\section{Semester-Long Simulation}

One of the biggest challenges facing business law professors is finding creative ways to present situations in which students can experience legal issues in a context that is relevant to what business lawyers do on a daily basis. One of the best ways to do this is with a course set up as a simulation that allows students to role-play as a business lawyer representing a hypothetical client and interacting with that client as a lawyer would-including all the various aspects of communication discussed in this article. Law students often have an underdeveloped view of business lawyers and the business people they represent. Putting the students in a role_-and really making them live that role_-allows them to develop some empathy for the characters in the simulation and perhaps a better appreciation for business lawyers and their clients.

In a simulation course, students perform all kinds of transactional lawyering activities, such as analyzing a term sheet, drafting documents and preparing for a closing. ${ }^{13}$ Simulations allow students to "get their hands dirty" by actually engaging in the professional practices in which lawyers engage. Some in the academy regard such exercises as too "vocational" to count as academic exercises, but in reality, these hands-on exercises only work if the students are well-grounded in theory.

\footnotetext{
13 See Karl S. Okamoto, Learning and Learning-to-Learn By Doing: Simulating Corporate Practice in Law School, 45 J. LEGAL ED. 498, 498-510 (1995).
} 
Discussions among legal educators about the best way to educate future lawyers sometimes break down into a false dichotomy between "theory" and "practice," as if the two notions cannot co-exist in the same course. Such reductionist thinking is overly simplistic. Theory informs practice; practice applies theory. They complement each other, and a good transactional lawyer is comfortable in both worlds.

In the context of teaching effective communication, students must be encouraged to take a step back from activities they have been pretty good at for a long time-writing and speaking - to think about how they could do those things more effectively. There are theories behind effective writing, compelling storytelling, and persuasive speaking. Theory, however, must be put to the test by devising ways for students to apply it in the context of professional practice.

One approach to achieving that marriage of theory and practice is a simulation course called the Transactional Lawyering Seminar. Although the seminar is designed around a hypothetical M\&A transaction where a venture fund purchases a division of an existing corporation, the course is not so much about a particular substantive area of law as it is about the practice of transactional law. The goal of the course is to let students know what transactional lawyers do and why they do it.

Following a hypothetical deal based on the problem in Prof. Karl Okamoto's first Transactional LawMeets ${ }^{\circledR}$ competition, students interview a client, write a counseling letter to that client, work with financial statements, draft a term sheet for a deal, mark up the other side's term sheet, negotiate on behalf of the client, and make realistic plans for completing the transaction.

The seminar is a limited enrollment class, with 16 students. Half of the students play the role of counsel to the seller, and the other half play counsel to the buyer. They do this in teams of two, so four teams serve as buyer's counsel and four teams serve as seller's counsel. Since lawyers often work in teams, this is a deliberate part of the course design.

That's the "what lawyers do" part.

On the matter of "why they do it," students are assigned readings that are at least conceptual, if not theoretical, on topics such as clear writing, storytelling, counseling, drafting, risk management, strategy, accounting, project management, interviewing, negotiation, and other topics. When students object that they already know how to write to clients or tell a story, they are reminded that there's nothing as practical as 
a good theory. Good theories help lawyers understand the world and guide them when they find themselves in unfamiliar territory. In a world that changes as frequently as ours does, this is practical indeed.

During class sessions, the entire group discusses the day's readings and relates the lessons to the hypothetical transaction. Classes are real discussions, with no computers allowed. Students must submit three questions by 9:00 P.M. the night before class, showing that they read the material. Those questions form the basis of the next day's class discussion. To keep the class focused on discussion and exercises, the professor "flips" the presentation to deliver substantive information online. In this way, class time is devoted to applying, as opposed to developing, ideas. Outside of class, student teams interact with the professor playing the role of the client.

\section{Exercise Combining Issue-Spotting, Research, Analysis, and Client Advice}

One of the great advantages of simulated exercises is that the professor can make happen whatever the professor wants to happen. In the following exercise, students are placed in a situation that replicates one of the core activities of the transactional lawyer: translating law into an action plan to solve a client's problem.

By either a reading or a brief lecture, students are exposed to the existence of reduction-in-force laws, such as the Worker Adjustment and Retraining Notification (WARN) Act ${ }^{14}$ and similar state laws. Although they are far from experts in the implications and details of the WARN Act, students are made aware of its general contours and the penalties imposed on employers who reduce the size of a workforce within short time frames.

Students represent Morgan Buyer, who is in negotiations with Lee Seller to purchase Seller's roughly two million dollar outdoor furniture manufacturing business. The business currently has seventy-eight full-time employees, eight of whom are on temporary layoff. Twelve of the seventyeight do sewing activities, and ten of the seventy-eight work on the loading dock. ${ }^{15}$ Seller is adamantly opposed to having any of the employees terminated in the purchase process.

\footnotetext{
${ }^{14}$ Worker Adjustment and Retraining Notification (WARN) Act of 1988, 29 U.S.C. SS 2101-2109 (2012).

15 These numbers work to make an interesting analysis under the Illinois Worker Adjustment and Retraining Notification Act (820 IlL. Comp. STAT. 65/1 (2005)).
} 
Buyer explains to student-counsel that Buyer wants to terminate the sewing employees and replace them with technology, a process that may take several months after the deal closes. Buyer also explains that Buyer wishes to replace the loading dock employees, perhaps by engaging a company that does loading services, or perhaps by engaging the current loading dock employees as independent contractors (hoping to avoid the worker's compensation liabilities and disruptions that plague this component of the workforce). In either event, the current ten loading dock employees would cease being employees. This move, Buyer says, could be accomplished quickly after the deal closes.

Students are given a few hours to consider the client's wishes in light of statutory requirements and to formulate a plan or plans that will allow the client to accomplish all or most of the client's goals without triggering the WARN Act's (or comparable state statutes') fines, penalties or warnings. Each student or pair of students meets with Morgan Buyer to explain the plans. Morgan is best played by a person with business experience, but in any event is scripted with good plans developed by the professor so that Morgan will be pleased or disappointed with the studentcounsel's proposed plans.

This exercise immerses the student into the role of transactional lawyer and sets up a realistic lawyer-client interaction in which the client has made business judgments and the lawyer's job, if the law allows, is to develop action plans that accomplish the client's lawful goals.

\section{Flawed Contract Review Exercise}

A good multi-skill building exercise is to give students a flawed contract (such as an independent contractor agreement, lease, restrictive covenant, or similar agreement) to review.

In this exercise, students conduct research about the requirements for the type of agreement, identify substantive issues with the contract, and write a short one-page memo to the business client about these issues, along with questions for the client about business terms. ${ }^{16}$ Students interview the

\footnotetext{
Numbers should be adjusted by the professor if other state statutes or the federal WARN Act is used.

16 See Thomson Reuters Practical Law, https://legal.thomsonreuters.com/en/products/practical-law (last visited Aug. 31, 2018) (provides excellent resources for students, including practice notes, standard annotated forms, and checklists).
} 
client as a group in class, with the professor playing the role of client, and every student asks at least one question.

After the interview, the professor provides feedback to the class about the method of interviewing and quality of questions, including the need for open-ended questions, especially at the beginning of the interview. The professor also provides feedback to the students about the appropriate tone, format, and substance of the memo for a business client, such as the need to be positive, minimize detail, and use bullet points and headings.

The final step in the exercise is for students to revise the agreement, addressing substantive provisions, business terms, and stylistic issues.

\section{Transactional Attorneys as "Clients" in Simulated Transactional Negotiation}

One of the challenges in creating an effective simulated sophisticated commercial negotiation is to provide simulated clients who can provide the realism of the business client but within the context of focusing on teaching the role of the transactional lawyer. An excellent source of these "clients" is transactional attorneys, especially alumni of the law school who are committed to giving succeeding generations of transactional law students the transactional legal knowledge and skills that they might not have had an opportunity to develop within their own earlier law school experience.

Practicing transactional attorneys are especially helpful in being able to provide a realistic simulation of a client with a particular background or experience (such as a client who is personally concerned about his or her workforce when selling the family business or a client whose business is basically a series of acquisitions within a particular industry). Attorneys with experience in these types of transactions can capture the motivations and typical reactions in their portrayal of these types of clients, and their specific knowledge of the lawyer's role in representing these types of clients generally produces much more "realistic" simulations than portrayals by non-attorneys such as actors or business students.

Most important, if one is fortunate enough to have transactional attorneys with a commitment to mentoring the next generation available to play roles as clients in simulations, the students then have the opportunity to debrief their simulations with the benefit of attorneys who not only provide feedback in their roles as clients, but who can also 
demonstrate, as attorneys, how they might handle a client interview or a negotiation with counsel for the other side. These types of debriefings, led by the professor, in which students discuss transactional law and skills with transactional attorneys they know and trust after a couple of weeks of successful simulation, provide invaluable opportunities for students to probe and understand the subtleties of written and oral communication in the context of a business transaction.

\section{Conclusion}

The exercises described above represent only a fraction of the potential simulations that a professor can use to teach communication skills in the context of transactional law. Various factors, such as class size and availability of local practitioners and other resources, will necessarily affect the viability of these examples. Nevertheless, teaching communication skills is a key aspect of transactional law and skills education, especially in view of the relative focus on litigation-based communication in the law school curriculum. Transactional lawyers communicate differently from litigators in important respects, and students need to understand these differences and gain experience in both contexts as part of their legal education. 


\section{APPENDIX A: ACTIVE LISTENING CHECKLIST}

\section{Body language}

- Eye contact

- Open and welcoming posture

- Facial expressions

\section{Mental engagement}

- Rapt attention

- Avoidance of daydreaming

\section{Following}

- No interruptions or talking over

- Questions for clarification/more information

- Resistance to being defensive or giving advice

- Attention to emotions and underlying motives

- Attention to what is not being said

\section{Reflective Listening}

- Restatements of what's been heard

- Asking to be corrected

- Asking for additional information

\section{Communication}

- Using "I" instead of "you"

- Avoiding "should" and "ought"

- Avoiding “yes, but...”

- Replacing "why" with "help me understand" 


\section{APPENDIX B: CODE OF CONDUCT EXERCISE}

\section{YOU ARE IN-HOUSE COUNSEL:WHAT'S YOUR ADVICE?}

1. An attorney in your office tells you that an outside law firm has offered the legal department 2 tickets to the NCAA Championship worth $\$ 750$ each.

2. A manager wants to know about purchasing signs from the sign company owned by the manager's brother for an event that your organization is planning.

3. An internal auditor reports to you that a manager in the accounts payable department is delaying paying bills that are due in the last month of the fiscal year until the following month.

4. A manager asks you if it's okay to hire the manager's daughter-inlaw for a position in the manager's department since she would be perfect for the job.

5. The CFO asks you if it's okay for the CFO to serve on the board of a private, for-profit organization.

6. An IT executive who attended a Microsoft-sponsored conference last week wants to know about keeping a free Surface tablet that Microsoft handed out to conference participants.

7. An IT employee asks you about working part-time on the weekends for a computer programming business that does work for your organization.

8. An employee asks you about including a back massage on the employee's expense report after two very stressful weeks of representing your organization in high pressure meetings overseas.

9. An employee asks you about using the company's computer for personal reasons during the lunch break.

10. An employee asks you if it's okay to post something on Facebook about a new product that's being rolled out. 


\section{APPENDIX C: EVALUATION CRITERIA FORM BUSINESS NEGOTIATIONS}

Number of Team Being Evaluated:

Please complete the following assessment of the Team you are evaluating using a 1-5 scale, with 5 representing "very strong" and 1 representing "very weak."

\section{NEGOTIATION PLANNING}

- Team demonstrated a clear understanding of the facts and issues and its client's interests and objectives

- Team appeared to have a strategy and clear goals and priorities

2. FLEXIBILITY

- Team was flexible in adapting its strategy to new information and other developments during the negotiation

3. COMMUNICATION

- Team communicated in a clear and articulate way

- Team displayed confidence and persuasiveness by means of speech, tone, eye contact, and body language

4. INFORMATION-GATHERING

- Team was effective in asking questions and drawing out the interests and objectives of the other side

- Team identified mutual interests of the parties 


\section{ACTIVE LISTENING}

- Team respectfully listened to the other side and did not interrupt the other side

- Team demonstrated understanding of the other side's interests and objectives

\section{CREATIVE PROBLEM-SOLVING}

- Team was creative in developing solutions to problems

- Team demonstrated effort to find solutions with mutual gains

\section{CLIENT ADVOCACY}

- Team clearly expressed client's interests, goals, and priorities throughout the negotiation

- Team effectively advocated for its client and protected the client's interests

\section{OUTCOME}

- Team appeared to achieve (or was on the road to achieving) an outcome that met the objectives of its client

- Team adequately and accurately summarized points of agreement and any unresolved issues at end of negotiation

\section{ORGANIZATION}

- Team followed a clearly stated agenda

- Team periodically used recaps to keep discussion organized 


\section{EFFICIENCY}

- Team effectively used the allotted time

- Team took break (if any) at appropriate time and made effective use of break

\section{TEAMWORK}

- Team worked well together in sharing responsibility and providing mutual backup and support

- Team did not talk over each other

\section{WORKING RELATIONSHIP WITH OTHER}

\section{TEAM}

- Team was receptive to the other team's offers and ideas

- Team established a positive working relationship with the other team for future negotiations

\section{PROFESSIONALISM}

- Team conducted the negotiation in a professional manner and appeared to observe ethical standards

\section{TOTAL POINTS}

COMMENTS: Please add any comments you may have. 


\section{APPENDIX D: EVALUATION FORM}

\section{Presentation}

Date:

Student:

Evaluation Scale:

\begin{tabular}{|l|l|l|}
\hline $\begin{array}{l}\text { Needs Improvement } \\
(0-1 \text { points })\end{array}$ & $\begin{array}{l}\text { Competent } \\
(2-3 \text { points })\end{array}$ & $\begin{array}{l}\text { Excellent } \\
(4-5 \text { points })\end{array}$ \\
\hline
\end{tabular}

\begin{tabular}{|c|c|c|}
\hline CATEGORY & SCORE & COMMENTS \\
\hline $\begin{array}{l}\text { I. Preparation and } \\
\text { Knowledge }\end{array}$ & & \\
\hline $\begin{array}{l}\text { - Appears adequately } \\
\text { prepared }\end{array}$ & & \\
\hline $\begin{array}{l}\text { - Demonstrates } \\
\text { command of subject } \\
\text { matter }\end{array}$ & & \\
\hline II. Presentation Content & & \\
\hline $\begin{array}{l}\text { - Addresses issues in } \\
\text { sufficient depth for } \\
\text { audience }\end{array}$ & & \\
\hline $\begin{array}{l}\text { - Explains issues with } \\
\text { clarity }\end{array}$ & & \\
\hline $\begin{array}{l}\text { - Conveys meaningful } \\
\text { insights in addition to } \\
\text { facts }\end{array}$ & & \\
\hline & & \\
\hline
\end{tabular}




\begin{tabular}{|c|c|c|}
\hline $\begin{array}{l}\text { III. Organization and } \\
\text { Efficiency }\end{array}$ & & \\
\hline $\begin{array}{l}\text { - Presents issues in } \\
\text { organized way }\end{array}$ & & \\
\hline $\begin{array}{l}\text { - Focuses on issues } \\
\text { without unnecessary } \\
\text { detail }\end{array}$ & & \\
\hline $\begin{array}{l}\text { - Uses time wisely and } \\
\text { covers important } \\
\text { issues in allotted time }\end{array}$ & & \\
\hline IV. Communication & & \\
\hline $\begin{array}{l}\text { - Speaks clearly and } \\
\text { articulately }\end{array}$ & & \\
\hline $\begin{array}{lr}\text { - Speaks } & \text { with } \\
\text { appropriate } & \text { volume, } \\
\text { speed, and projection }\end{array}$ & & \\
\hline $\begin{array}{l}\text { - Maintains the interest } \\
\text { of the audience }\end{array}$ & & \\
\hline $\begin{array}{l}\text { - Conveys enthusiasm } \\
\text { for the topic and has } \\
\text { good energy level }\end{array}$ & & \\
\hline $\begin{array}{l}\text { - Invites and leads } \\
\text { discussion effectively }\end{array}$ & & \\
\hline $\begin{array}{l}\text { V. Use of Slides or Other } \\
\text { Visual Materials }\end{array}$ & & \\
\hline $\begin{array}{l}\text { - Uses appropriate } \\
\text { amount of text }\end{array}$ & & \\
\hline $\begin{array}{l}\text { - Uses text size and } \\
\text { color that are readable }\end{array}$ & & \\
\hline
\end{tabular}




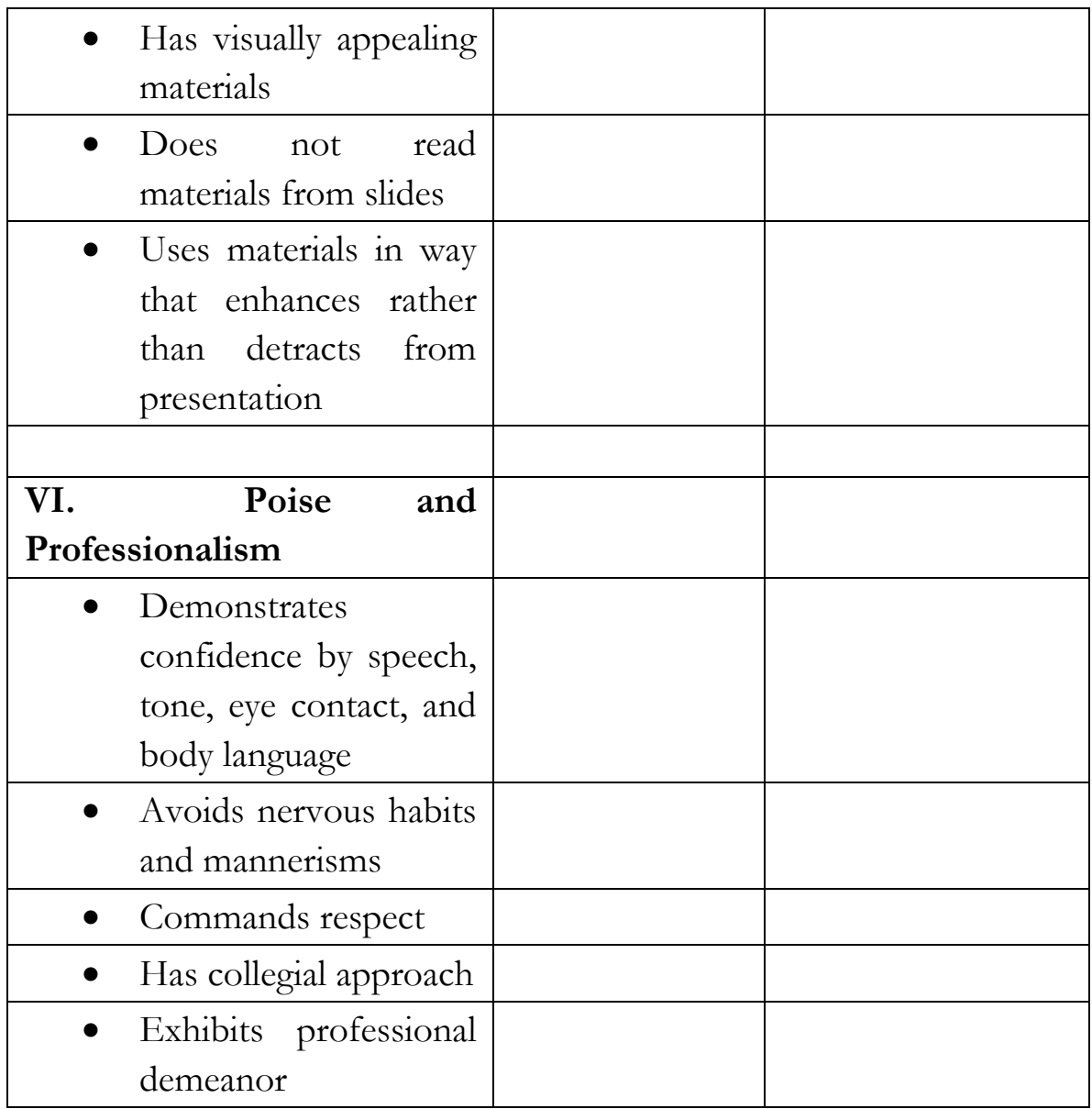

\section{APPENDIX E: PEER EVALUATION}

Student Presenter(s):

1. What did you find particularly interesting or learn as a result of this presentation?

2. What did you find particularly effective in the style of presentation?

3. What do you think could be improved in the style of presentation? 